\title{
Magnesium Sources and Inoculation with Azospirillum brasilense in the Initial Development of Maize
}

\author{
Roberto Cecatto Júnior ${ }^{1}$, Vandeir Francisco Guimarães ${ }^{1}$, Lucas Guilherme Bulegon ${ }^{1}$, Anderson Daniel Suss ${ }^{1}$, \\ Adriano Mitio Inigaki ${ }^{1} \&$ Tauane Santos Brito ${ }^{1}$ \\ ${ }^{1}$ Agricultural Sciences Center, Parana Western State University, Marechal Cândido Rondon, PR, Brazil \\ Correspondence: Vandeir Francisco Guimarães, Agricultural Sciences Center, Parana Western State University, \\ Marechal Cândido Rondon, PR, Brazil. Tel: 55-453-284-7878. E-mail: vandeirfg@yahoo.com.br
}

Received: February 24, 2019

Accepted: April 10, 2019 Online Published: May 31, 2019

doi:10.5539/jas.v11n7p170

URL: https://doi.org/10.5539/jas.v11n7p170

\begin{abstract}
The aim was to evaluate the initial development of maize plants when submitted to mineral fertilization with magnesium sources in the presence or absence of seed inoculation with Azospirillum brasilense. To do so, was conducted an experiment in greenhouse. In the essay was adopted a randomized blocks design, in a factorial scheme $3 \times 2$, represented by the magnesium sources: magnesium sulfate $\left(\mathrm{MgSO}_{4}\right)$, magnesium oxide $(\mathrm{MgO})$ and control without $\mathrm{Mg}$ fertilization, in the presence or absence of inoculation with A. brasilense. The $\mathrm{Mg}$ sources were supplied with a dose of $30 \mathrm{~kg} \mathrm{ha}^{-1}$, being homogenized in the substrate before sowing the crop. The analysis were carried out in the V4 stage, evaluating: basal stem diameter (BSD); relative chlorophyll content (SPAD index), leaf dry mass (LDM), stem + sheath blade dry mass (SSDM) and root dry mass (RDM). No differences were observed for the factors interaction and for the $\mathrm{Mg}$ sources. When considered the seed inoculation there was increases of $7.1 \% ; 6.61 \% ; 19.23 \% ; 28.32 \%$; and $15.17 \%$, for basal stem diameter, SPAD index, leaf dry mass, stem + sheath blade dry mass and roots, respectively. The inoculation of maize seeds with $A$. brasilense increases the initial development of maize plants and the SPAD index in greenhouse conditions in the V4, while the fertilization with the magnesium sources do not interfere in the maize development.
\end{abstract}

Keywords: Zea mays L., Plant growth promoting bacteria, SPAD index

\section{Introduction}

The maize crop (Zea mays L.) has a great relevance in the world agricultural production, being the main cereal produced. For this, many techniques were developed and implanted for the crop management, allowing yield increases.

Among the production techniques that ensure the expression of the yield potential is highlighted the mineral fertilization of plants with macro and micro nutrients, which provide an adequate of the crop. Among the macronutrients, the magnesium has an important rule for the photosynthesis, being part of the chlorophyll molecule and integrating and activating enzymes, being the ribulose-1,5-bifosphate (RuBP) carboxylases/oxygenase (Taiz \& Zeiger, 2013) the most relevant. The magnesium deficiency causes the chloroplasts degradation, thus, compromise the photosynthesis once it directly affects the $\mathrm{CO}_{2}$ diffusion.

With the technological advances, other ways started to be studied aiming maximize the maize yield potential, among them is the maize seed inoculation with plant growth promoting bacteria (PGPB), because they stimulate the plant development from the supply of vegetal hormones such as auxins, gibberellins and cytokinin (Kuss et al., 2007), providing, in many cases, more vigorous and productive plants (Cassan \& Diaz-Zorita, 2016).

Among the bacteria species studied for plant growth promotion is the Azospirillum brasilense. This specie is characterized as a facultative endophytic, that can colonize both the rhizosphere and the plants interior (Olivares et al., 2017). Among the positive effects of $A$. brasilense in the plant development stand out the higher nutrient absorption (Hungria et al., 2010), having thus a potential synergy effect when associated to the mineral fertilization of plants.

As follows, the aim is to study the interactions with different cultivated plants and higher efficiency of the PGPB. One of the aspects of this interaction is related to the higher use of nutrients by the inoculated plants, highlighting studies with nitrogen, however, also integrate the list, macronutrients such as phosphorus and 
potassium (Hungria et al., 2010). When considering the fertilization with magnesium, although it is an important nutrient for essential physiological processes of the plant, there are no reports about this nutrient interaction with PGPB in the maize crop.

Therefore, the inoculation of $A$. brasilense associated to magnesium fertilization may help the plant development with higher chlorophyll relative content and higher development, given that both have influences in important biochemical and physiological reactions in plants.

Thus, the aim was to evaluate the initial development of maize plants when submitted to mineral fertilization with magnesium sources in the presence or absence of seed inoculation with Azospirillum brasilense.

\section{Material and Methods}

\subsection{Experiment Description}

The experiment was conducted into a protected environment with roofs in arc, covered with low density polyethylene film with $150 \mu$ thickness and anti-UV protection, with sides protected with white screen with $40 \%$ shading, at the experimental station Professor Dr. Mario César Lopes, located at the coordinates $24^{\circ} 558^{\prime} \mathrm{S}$ and $54^{\circ} 045^{\prime} \mathrm{W}$, located at the State University of Western Paraná-Unioeste, Marechal Cândido Rondon, Paraná.

\subsection{Experimental Design}

The experiment was conducted under a randomized block design in a factorial scheme $3 \times 2$ with four replicates, being the first factor composed by magnesium fertilizations: magnesium sulfate $\left(\mathrm{MgSO}_{4}\right)$; magnesium oxide $(\mathrm{MgO})$ and control (without $\mathrm{Mg}$ fertilization). The second factor involved treatments related to inoculation with growth promoting bacteria $A$. brasilense being: control (without inoculation) and treatment with inoculation.

\subsection{Conduction}

For the experiment conduction were used polyethylene pots with capacity to $4 \mathrm{dm}^{3}$ which received as substrate a mixture of: soil from the A horizon of an Oxisol (Santos et al., 2013), sand and organic compound in the proportion of $2: 1: 1$, respectively, being that at the moment when the experiment was installed the substrate presented the chemical characteristics shown at (Table 1).

Table 1. Chemical and physical characteristics of a substrate proveniente from the mixture of an Oxisol (horizon A) with sand and organic compound in the proportion 2:1:1, respectively, 2016/2017

\begin{tabular}{|c|c|c|c|c|c|c|c|c|c|c|}
\hline $\mathrm{P}$ & $\mathrm{OM}$ & $\mathrm{pH}$ & $\mathrm{H}+\mathrm{Al}$ & $\mathrm{Al}^{3+}$ & $\mathrm{K}^{+}$ & $\mathrm{Ca}^{2+}$ & $\mathrm{Mg}^{2+}$ & B & CEC & V \\
\hline $\mathrm{mg} \mathrm{dm}^{-3}$ & $\mathrm{~g} \mathrm{dm}^{-3}$ & $\mathrm{CaCl}_{2}$ & - ----- & - & - & $\mathrm{mol}_{\mathrm{c}} \mathrm{d}$ & 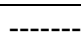 & & & $\%$ \\
\hline 25.27 & 4.10 & 5.75 & 2.96 & 0.00 & 0.08 & 2.94 & 1.11 & 4.13 & 6.68 & 80.60 \\
\hline
\end{tabular}

Note. $\mathrm{OM}=$ Organic matter; $\mathrm{CEC}=$ Cation exchange capacity; $\mathrm{V}=$ Percent Saturation of Bases; $\mathrm{P}$ and $\mathrm{K}$ $\left(\mathrm{Mehlich}^{-1}\right)$; $\mathrm{Ca}, \mathrm{Mg}$ and $\mathrm{Al}^{3+}(\mathrm{KCl} 1 \mathrm{~mol}) ; \mathrm{Al}+\mathrm{H}\left(\right.$ calcium acetate $\left.0.5 \mathrm{~mol} \mathrm{~L}{ }^{-1}\right)$.

The substrate was fertilized with: $100 \mathrm{mg} \mathrm{dm}^{-3}$ of $\mathrm{N}$ as urea, $150 \mathrm{mg} \mathrm{dm}^{-3}$ of $\mathrm{K}$ as potassium chloride and $300 \mathrm{mg}$ $\mathrm{dm}^{-3}$ of $\mathrm{P}$ as super simple phosphate, which added $40 \mathrm{mg} \mathrm{dm}^{-3}$ of $\mathrm{S}$ and $85 \mathrm{mg} \mathrm{dm}^{-3}$ of Ca (Novaes et al., 1991). For the magnesium fertilization, it was applied magnesium sulfate $\left(\mathrm{MgSO}_{4}\right)$ and magnesium oxide $(\mathrm{MgO})$, following the crop need of $15 \mathrm{mg} \mathrm{dm}^{-3}$ which corresponded to a dose of $30 \mathrm{~kg} \mathrm{ha}^{-1}$ of $\mathrm{Mg}$ (Broch \& Ranno, 2011).

Seeds of the hybrid 30F53VYHR ${ }^{\circledR}$ Pionner were used for the experiment, which were inoculated with $A$. brasilense strains AbV5 and AbV6 (commercial product containing $2 \times 10^{8} \mathrm{CFU} \mathrm{mL}^{-1}$ ) with dose of $100 \mathrm{~mL}$ to each 60.000 maize seeds, which were homogenized and kept on the shade for about 30 minutes. Then were seeded six seeds per pot at the three centimeters depth. After 5 days of emergence, thinning was done leaving 2 plants per pot for the conduction of the experiment.

Irrigation was daily made, adding water until the pots reached the field capacity. Plants were constantly monitored, not being necessary the realization of cultural managements or cover fertilization with $\mathrm{N}$ until the V4 stage when they were evaluated.

\subsection{Evaluations}

The non-destructive and destructive evaluations were carried at the 25 days after emergence (DAE), when maize plants reached a point with four completely expanded leaves, characterizing then the V4 stage. 
For the non-destructive analysis was determined the relative chlorophyll content (SPAD index) obtained with aid of the portable apparel SPAD-502-Plus Konica Minolta, by means of the measurement on the four totally expanded leaves, being performed three readings per leaf, of each plant of each pot. It was also measured the basal stem diameter (SD), using a digital caliper on each plant of each pot, expressed in centimeters $(\mathrm{cm})$.

Posteriorly, plants were cut right above ground and sectioned into leaves, stem plus sheath blade and root system, being the samples stored in kraft paper bags and submitted to drying at $65{ }^{\circ} \mathrm{C}$ in air forced circulation oven for 72 hours. Then weighing was made in an analytical balance chapel chamber type, determining the leaves dry mass (LDM), stem plus sheath blade dry mass (SSDM) and root dry mass (RDM), all results expressed in grams (g).

\subsection{Statistical Analysis}

The data were submitted to variance analysis at $5 \%$ probability and, when significant, the means were compared by the Tukey test at $5 \%$ of probability of error. The analyses were carried with aid of software Sisvar (Ferreira, 2011).

\section{Results and Discussion}

For the parameters evaluated at the V4 stage of maize plants, under greenhouse condition, there was no interaction between inoculation of $A$. brasilense and magnesium fertilization $(\mathrm{p}>0.05)$. When was considered the parameter magnesium fertilization isolate, it did not influence any of the tested parameters. However, for the factor seed inoculation were observed differences for the values of stem plus sheath blade dry mass, leaf and root, besides the basal stem diameter and the SPAD index (Table 2).

Table 2. Summary of the variance analysis, square mean values of stem + sheath blade dry mass (SSDM), leaf dry mass (LDM), root dry mass (RDM), basal stem diameter (BSD) and SPAD index of maize in the vegetative stage V4, hybrid 30F53VYHR ${ }^{\circ}$, in function of $A$. brasilense inoculation, associated to magnesium fertilization in greenhouse in Marechal Cândido Rondon-PR

\begin{tabular}{|c|c|c|c|c|c|c|}
\hline VF & DF & SSDM & LDM & RDM & BSD & SPAD \\
\hline Block & 3 & $0.067^{\mathrm{ns}}$ & $0.028^{\mathrm{ns}}$ & $0.0004^{\mathrm{ns}}$ & $0.00008^{\mathrm{ns}}$ & $0.502^{\mathrm{ns}}$ \\
\hline Magnesium (Mg) & 2 & $0.098^{\mathrm{ns}}$ & $0.033^{\mathrm{ns}}$ & $0.021^{\mathrm{ns}}$ & $0.00008^{\mathrm{ns}}$ & $0.070^{\mathrm{ns}}$ \\
\hline Inoculation (I) & 1 & $0.604^{* *}$ & $0.126^{* *}$ & $0.434^{* *}$ & $0.00303^{* *}$ & $37.525^{\text {** }}$ \\
\hline $\mathrm{Mg} * \mathrm{I}$ & 2 & $0.018^{\mathrm{ns}}$ & $0.026^{\mathrm{ns}}$ & $0.012^{\mathrm{ns}}$ & $0.00001^{\mathrm{ns}}$ & $0.748^{\mathrm{ns}}$ \\
\hline Residual & 15 & 0.029 & 0.014 & 0.010 & 0.00016 & 0.788 \\
\hline $\mathrm{CV}(\%)$ & & 13.20 & 14.22 & 5.28 & 4.34 & 2.27 \\
\hline \multicolumn{7}{|c|}{ Summary of the averages for fertilization with magnesium } \\
\hline & & \multicolumn{3}{|c|}{$\mathrm{g}^{-1}$ plant } & \multicolumn{2}{|c|}{$\mathrm{mm}^{-1}$ plant } \\
\hline Control & & 1.245 & 0.856 & 1.992 & 29.200 & 38.955 \\
\hline Magnesium oxide & & 1.211 & 0.794 & 1.807 & 29.900 & 39.140 \\
\hline Magnesium sulphate & & 1.419 & 0.922 & 1.926 & 29.700 & 39.074 \\
\hline
\end{tabular}

Note. ${ }^{\text {ns}} ;{ }^{* *} ; *$ not significant, significant at $1 \%$ and $5 \%$ probability, respectively, by the $\mathrm{F}$ test.

Possibly, the absence of meaningful response from the plants to the magnesium fertilization, as well as the absence of significant interaction between the factors is related to the high magnesium content $\left(1.11 \mathrm{cmol}_{\mathrm{c}} \mathrm{dm}^{-3}\right)$ on the substrate, since that magnesium contents on the soil between 0,8 and $1 \mathrm{cmol}_{\mathrm{c}} \mathrm{dm}^{-3}$ ) are considered high (SBCS, 2004). However, even with the adequate content in the soil, study performed by Altarugio et al. (2017) showed increase in the foliar magnesium content and increase in yield in response to foliar fertilization with the nutrient, in all application times. However, the authors did not find increases in the SPAD index, result that was expected due to the fact that the magnesium is part of the chlorophyll molecules (Taiz \& Zeiger, 2013). Other point, the inexistence of response to magnesium fertilization in the present study may be related to its absorption rate, once that the maximum absorption by the maize plants occur at between 80 to 90 days after the emergence (Andrade, 1975; Boroni et al., 2010). In addition, this effect can be related to the fact that the present study considered the magnesium sources, being that both provided the same dose of $\mathrm{Mg}$, that is, as both are soluble sources plants used the sources in a similar way, not obtaining differences between the studied sources, while in the control the amount of $\mathrm{Mg}$ in the soil was enough to supply the initial demand from the plant for the nutrient, not resulting in development reduction as elucidated by the minimum law, that is, the $\mathrm{Mg}$ did not limit the crop development. 
Considering the isolate effect of the inoculation over the stem plus sheath blade dry mass and leaves dry mass, it is observed that the parameters were stimulated by the inoculation of $A$. brasilense with increases in the order of $28.32 \%$ and $19.23 \%$ respectively, in relation to non-inoculated plants (Figure 1).

Quadros et al. (2014), in relation to stem and leaves dry mass, evaluating the effect of the inoculation of Azospirillum in maize hybrids with nitrogen fertilization, observed increases of up to $53 \%$ in the aerial dry mass yield in inoculated plants in relation to non-inoculated.
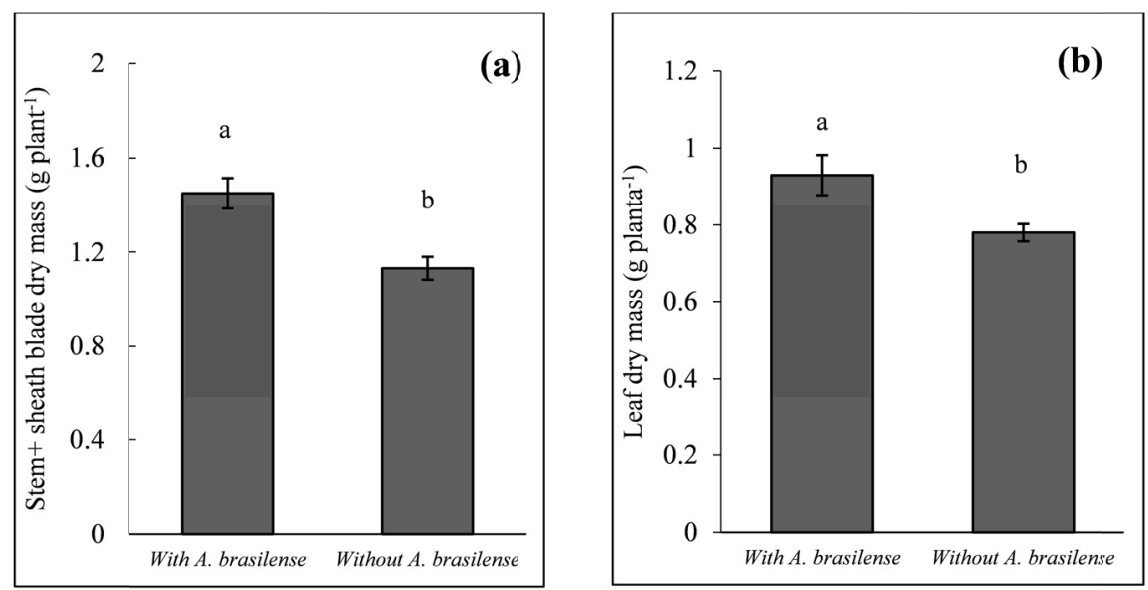

Figure 1. Means of stem+sheath blade dry mass (a) and leaf dry mass (b) of maize plants with and without inoculation of $A$. brasilense, in the vegetative stage (V4), hybrid 30F53VYHR ${ }^{\circledR}$, in greenhouse conditions, in Marechal Cândido Rondon-PR

Note. Means followed by upper case letters in the line do not differ from each other by the Tukey test at 5\% probability.

The inoculation of $A$. brasilense in the maize seeds, influenced positively the root dry mass, providing an increase of $15.17 \%$ in relation to non-inoculated plants. Similarly, the stem diameter was also influenced by the inoculation, with increase of 7\% in inoculated plants to non-inoculated plants (Figure 2).

Reis Junior et al. (2008) evaluating the morphological response of maize plants inoculated with A. amazonenses also found higher root dry mass production in inoculated plants. Equally, work carried with inoculation of $A$. brasilense in rice seeds found increases in the root development of 24.7\% (Guimarães et al., 2013).

The significant effect for stem plus sheath blade dry mass, leaf and root in maize plants inoculated with $A$. brasilense must be bonded to the vegetal hormones production, such as auxins, gibberellins and cytokines, by bacteria and possible interference of these on the plants (Moreira et al., 2010). These substances are plant growth promoters, that is, may have stimulated the development of stem and leaves of inoculated plants. In this way, Bashan et al. (2014) mention that the excretion of vegetal hormones, mainly the indoleacetic acid (IAA), by the Azospirillum that contributes to a higher growth of inoculated plants.

In the same way, the excretion of hormones by the PGPB, must be the explanation for the higher stem diameter in plants inoculated with $A$. brasilense, based on its capacity to provide auxins, gibberellins and cytokines which stimulate the higher plant development (Cassán et al., 2016). Besides, possibly resulting in higher resources absorption such as water and nutrients, by the higher root system development (Hungria et al., 2010), resulting in higher accumulation of organic compounds in the stem of inoculated plants. In relation to the stem diameter of inoculated plants, the increase may be associated to the highest accumulation of organic compounds, being the stem the main reserve organ in this period (Fancelli \& Dourado Neto, 2000). 

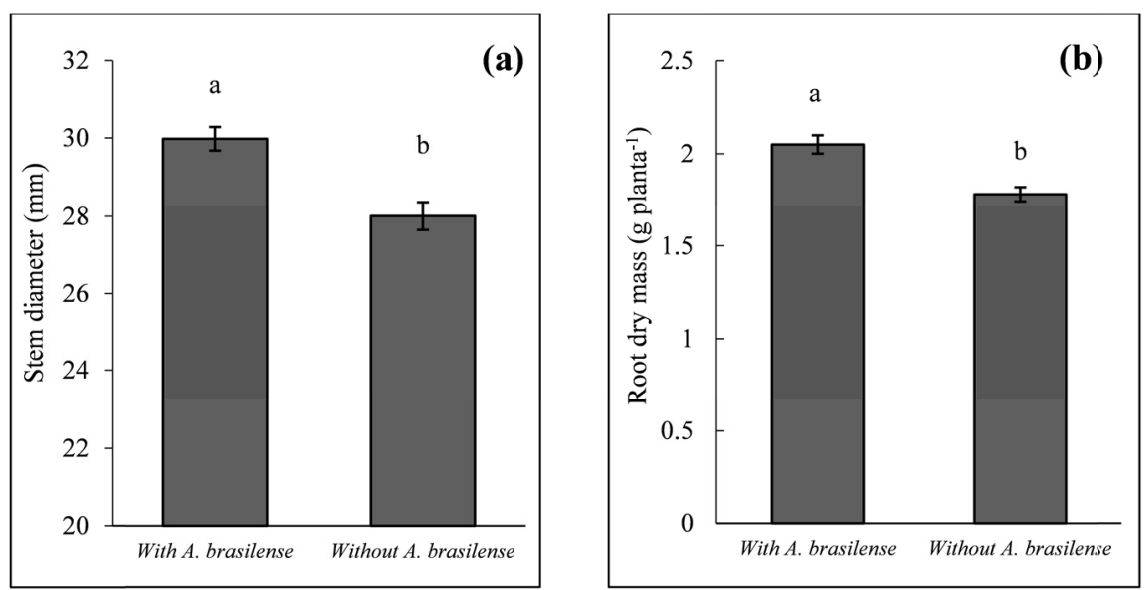

Figure 2. Means of stem diameter (a) and root dry mass (b) of maize plants with and without inoculation of $A$. brasilense, in the vegetative stage (V4), hybrid 30F53VYHR $\AA$, in greenhouse conditions, in Marechal Cândido Rondon-PR

Note. Means followed by upper case letters in the line do not differ from each other by the Tukey test at 5\% probability.

Dartora et al. (2013), working with the inoculation of A. brasilense + Herbaspirillum seropedicae associated to nitrogen fertilization in maize plants, verified increases of $15 \%$ in stem diameter, during the vegetative phase. The authors also associate the result to the supply of growth substances to the plants by the bacteria.

Plants which seeds were inoculated with $A$. brasilense presented higher SPAD index. Thus, it was observed an increase of $6.61 \%$ in relation to the treatment without inoculation (Figure 3). Similarly, Jordão et al. (2010), working with $A$. brasilense inoculation on maize seeds and nitrogen doses, found higher SPAD index in the inoculated treatments in relation to the ones without inoculation. For the authors, the highest SPAD index is related to the higher foliar nitrogen content. In this sense, the increase in the SPAD index for the maize crop related to nitrogen fertilization was already shown (Argenta, 2004). Equally, it was observed a proportional increase to the SPAD index in maize plants inoculated with A. brasilense (Quadros et al., 2014).

Thus, in this study, the increase in the SPAD index may be associated to the higher development of the root system in inoculated plants (Reis Júnior et al., 2008), resulting in higher nitrogen input (Hungria et al., 2010) and, consequently, increase of the SPAD index in relation to non-inoculated plants.

Another point for the increase in the SPAD index is related, according to Bashan et al. (2006), with stimulus of synthesis and maintenance of the activity of chlorophyll molecules during the initial development of wheat plants inoculated with $A$. brasilense. 


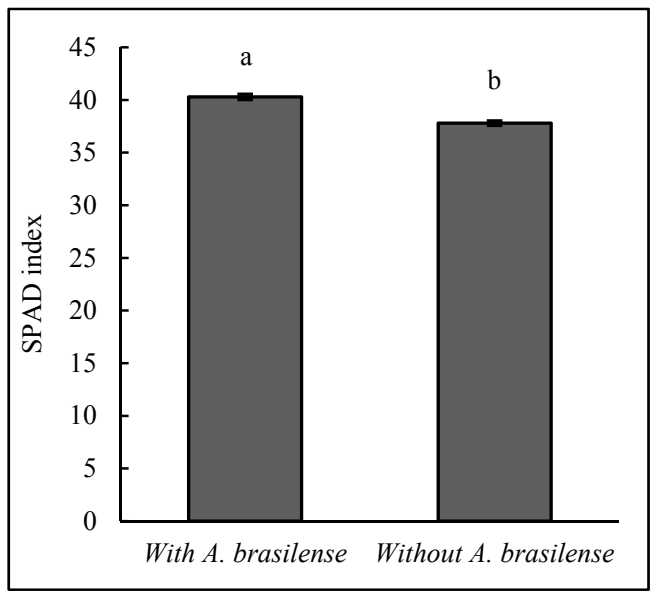

Figure 3. Means of SPAD index of maize plants with and without inoculation of $A$. brasilense, in the vegetative stage (V4), hybrid 30F53VYHR $®$, in greenhouse conditions, in Marechal Cândido Rondon-PR

Note. Means followed by upper case letters in the line do not differ from each other by the Tukey test at 5\% probability.

However, observed the benefits provided by the inoculation of maize seeds with A. brasilense, it can be concluded that the inoculation can provide cultural advantages originated from the greater initial development of maize plants. Since inoculated plants may be more capable of compete for environmental resources, water, nutrients (Hungria et al., 2010) result of greater root system development (Reis Júnior et al., 2008), besides greater foliar area (Guimarães et al., 2011).

Thus, observing the results obtained with the inoculation of $A$. brasilense and, the benefits that the use of inoculation may cause, it is verified that the use of inoculation of maize seeds is an alternative for the sustainable production of maize.

\section{Conclusion}

Magnesium sources, magnesium sulphate and magnesium oxide, applied via soil, did not interfere in the maize development.

The inoculation of maize seeds with A. brasilense increases the initial development of maize plants and the SPAD index in greenhouse conditions.

\section{Acknowledgment}

This study was financed in part by the Coordenação de Aperfeiçoamento de Pessoal de Nível Superior-Brasil (CAPES).

\section{References}

Altarugio, L. M., Loman, M. H., Nirschl, M. G., Silvano, R. G., Zavaschi, E., Carneiro, L. M. S. ... Otto, R. (2017). Yield performance of soybean and corn subjected to magnesium foliar spray. Pesquisa Agropecuária Brasileira, 52(12), 1185-1191. https://doi.org/10.1590/s0100-204×2017001200007

Andrade, A. G. (1975). Differential accumulation of nutrients by five maize cultivars (Zea mays L.). (Dissertation (12 f., Masters in Agronomy), School of Agronomy "Luiz de Queiroz", Piracicaba, Brazil).

Argenta, G., Silva, P. R. F., \& Sangoi, L. (2004). Leaf Relative chlorophyll content as an indicator parameter to predict nitrogen fertilization in maize. Ciência Rural, 34(5), 1379-1387. https://doi.org/10.1590/S010384782004000500009

Bashan, Y., Bustillos, J. J., Leyva, L. A., Hernandez, J. P., \& Bacilio, M. (2006). Increase in auxiliary photoprotective photosynthetic pigments in wheat seedlings induced by Azospirillum brasilense. Biology and Fertility of Soils, 42(4), 279-285.

Bashan, Y., Holguin, G., \& Bashan, L. E. (2004). Azospirillum-plant relationships: Physiological, molecular, agricultural, and environmental advances (1997-2003). Can J Microbiol, 55(8), 521-577. https://doi.org/ 10.1139/w04-035 
Borini, A. L. D., Lana, R. M. Q., \& Pereira, H. S. (2010). Absorption, accumulation and export of macronutrients in sweet corn grown under field conditions. Ciência e Agrotecnologia, 34, 1591-1597.

Broch, D. L., \& Ranno, S. K. (2011). Soil fertility, fertilization and nutrition of the corn crop. Technology and Production: Soy and maize (p. 39).

Cassán, F., \& Diaz-Zorita, M. (2016). Azospirillum sp. in current agriculture: Fom the laboratory to the field. Soil Biology \& Biochemistry, 113, 117-130. https://doi.org/10.1016/j.soilbio.2016.08.020

Dartora, J., Guimarães, V. F., Marini, D., \& Sander, G. (2013). Nitrogen fertilization associated with inoculation with Azospirillum brasilense and Herbaspirillum seropedicae in corn. Revista Brasileira de Engenharia Agricola e Ambiental, 17(10), 284-297. https://doi.org/10.1590/S1415-43662013001000001

Fancelli, A. L., \& Dourado-Neto, D. (2000). Corn production (1st ed., p. 360). Guaíba: Agropecuária.

Ferreira, D. F. (2011). A computer statistical analysis system. Ciência e Agrotecnologia, 35(6), 1039-1042. https://doi.org/10.1590/S1413-70542011000600001

Guimarães, S. L., Bonfim-Silva, E. M., Polizel, A. C., Moreira, J. C. F., \& Rezende, D. (2013). Initial growth of rice plants inoculated with Azospirillum spp. Revista Academica de Ciências Agrárias e Ambientais, 11(2), 45-50.

Guimarães, S. L., Bonfim-Silva, E. M., Kroth, B. E., Moreira, J. C. F., Rezende, D. (2011). Growth and initial development of Brachiaria decumbens inoculated with Azospirillum spp. Enciclopédia Biosfera, 7(13), 286-296.

Hungria, M. Campos, R. J., Souza, E. M., \& Pedrosa, F. O. (2010). Inoculation with selected strains of Azospirillum brasilense and A. lipoferum improves yields of maize and wheat in Brazil. Plant and Soil, 331(1), 413-425. https://doi.org/10.1007/s11104-009-0262-0

Jordão, L. T., Lima, F. F., Lima, R. S., Moretti, P. A. E., Pereira, H. V., Muniz, A. S., \& Oliveira, M. C. N. (2010). In the Brazilian Society of Soil Science, Relative content of chlorophyll in corn leaves inoculated with Azospirillum braziliense under different nitrogen doses and management with Brachiaria. Proceedings of the 29th Brazilian Meeting on Soil Fertility and Plant Nutrition (pp. 1-5). Guarapari, Brazil: SBCS. Retrieved from https://ainfo.cntstream/item/33879/1/id31707.pdf

Kuss, A. V., Kuss, V. V., Lovato, T., \& Flôres, M. L. (2007). Nitrogen fixation and production of indoleacetic acid in vitro by endophytic diazotrophic bacteria. Pesquisa Agropecuária Brasileira, 42(10), 1459-1465. https://doi.org/10.1590/S0100-204X2007001000013

Moreira, F. S. de., Silva, K., Nóbrega, R. S. A., \& Carvalho, F. (2010). Associative diazotrophic bacteria: Diversity, ecology and potential applications. Comunicata Scientiae, 1(2), 74-99

Novaes, R. F. De, Neves, J. C. L., \& Barros, N. F. DE (1991). Controlled environment test. In A. J. Oliveira, W. E. Garrido, J. D. Araujo, \& S. Lourenço (Eds.), Methods of research in soil fertility (pp. 189-253). Brasília DF: Embrapa-SE.

Olivares, F. L., Busato, J. G., Paula, A. M., Lima, L. S., Aguiar, N. O., \& Canellas, L. P. (2017). Plant growth promoting bacteria and humic substances: Crop promotion and mechanisms of action. Chemical and Biological Technologies in Agriculture, 4(1), 1-13. https://doi.org/10.1186/s40538-017-0112-x

Quadros, P. D., Roesch, L. F. W., Silva, P. R. F., Roehrs, D. D., \& Camargo, F. A. O. (2014). Agronomic performance in the field of maize hybrids inoculated with Azospirillum. Revista Ceres, 61(2), 209-218. https://doi.org/10.1590/S0034-737X2014000200008

Reis, Junior. F. B., Machado, C. T. T., Machado, A. T., \& Sodek, L. (2008). Inoculation of Azospirillum amazonense on two maize genotypes under different nitrogen regimes. Revista Brasileira de Ciências do Solo, 32(6), 1139-1146. https://doi.org/10.1590/S0100-06832008000300022

Santos, H. G. dos, Jacomine, P. D. T., Anjos, L. H. C. dos, Oliveira, J. B. de, Coelho, J. B. de, Lumbreras, J. F., \& Cunha, T. J. F. (2013). Brazilian system of soil classification (2nd ed., p. 353). Brasília: Embrapa.

SBCS (Sociedade Brasileira de Ciência do Solo). (2014). Manual of fertilization and liming of Rio Grande do Sul and Santa Catarina (10th ed., p. 400) Porto Alegre: SBCS.

Taiz, L., \& Zeiger, E. (2013). Plant Physiology (5th ed., p. 918). Porto Alegre: Artmed.

\section{Copyrights}


Copyright for this article is retained by the author(s), with first publication rights granted to the journal.

This is an open-access article distributed under the terms and conditions of the Creative Commons Attribution license (http://creativecommons.org/licenses/by/4.0/). 